\title{
The invertebrate ecology of the Chalk aquifer in England (UK)
}

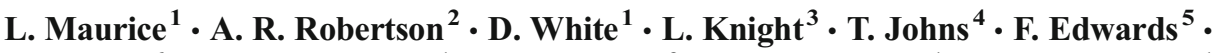 \\ M. Arietti ${ }^{6}$ - J. P. R. Sorensen ${ }^{1}$ - D. Weitowitz ${ }^{2}$ B. P. Marchant ${ }^{1}$ - J. P. Bloomfield ${ }^{1}$
}

Received: 26 February 2015 / Accepted: 27 October 2015 / Published online: 11 November 2015

(C) The Author(s) 2015. This article is published with open access at Springerlink.com

\begin{abstract}
The Chalk is an important water supply aquifer, yet ecosystems within it remain poorly understood. Boreholes (198) in seven areas of England (UK) were sampled to determine the importance of the Chalk aquifer as a habitat, and to improve understanding of how species are distributed. Stygobitic macro-invertebrates were remarkably common, and were recorded in $67 \%$ of boreholes in unconcealed Chalk, although they were not recorded in Chalk that is concealed by low-permeability strata and thus likely to be confined. Most species were found in shallow boreholes $(<21 \mathrm{~m})$ and boreholes with deep $(>50 \mathrm{~m})$ water tables, indicating that the habitat is vertically extensive. Stygobites were present in more boreholes in southern England than northern England (77\% compared to $38 \%$ ). Only two species were found in northern England compared to six in southern England, but overall seven of the eight stygobitic macroinvertebrate species found in England were detected in the Chalk. Two species are common in southern England, but
\end{abstract}

\section{Maurice}

loma@bgs.ac.uk

1 British Geological Survey, Maclean Building, Wallingford OX10 8BB, UK

2 Department of Life Sciences, Roehampton University, Holybourne Avenue, London SW15 4JD, UK

3 Hypogean Crustacea Recording Scheme: No. 1 The Linhay, North Kenwood Farm, Oxton, Nr. Kenton, Devon EX6 8EX, UK

4 Environment Agency, Red Kite House, Howberry Park, Wallingford OX10 8BD, UK

5 Centre for Ecology and Hydrology, Maclean Building, Wallingford OX10 8BB, UK

6 Affinity Water Limited, Tamblin Way, Hatfield, Hertfordshire AL10 9EZ, UK absent from northern England despite the presence of a continuous habitat prior to the Devensian glaciation. This suggests that either they did not survive glaciations in the north where glaciers were more extensive, or dispersal rates are slow and they have never colonised northern England. Subsurface ecosystems comprising aquatic macro-invertebrates and meiofauna, as well as the microbial organisms they interact with, are likely to be widespread in the Chalk aquifer. They represent an important contribution to biodiversity, and may influence biogeochemical cycles and provide other ecosystem services.

Keywords Ecology · Stygobite · Groundwater ecosystem · Chalk $\cdot$ UK

\section{Introduction}

This report describes the first national-scale study of groundwater ecology in a single geological unit, the Chalk aquifer (England, UK). Groundwater contains ecosystems comprising micro-organisms, meiofauna (organisms usually less than $1 \mathrm{~mm}$ in length), and larger macro-invertebrates (animals easily visible to the naked eye). In this study, boreholes were sampled for macro-invertebrates, which are the largest organisms present in non-cavernous groundwater, and Copepoda, which are meiofauna. The aims of the study were to improve understanding of regional-scale species distributions by sampling a consistent habitat that is present over a wide geographical area; and determine the importance of the Chalk as an ecological habitat by studying the extent of the habitat and the prevalence of invertebrates within the aquifer.

Invertebrate species that are obligatory inhabitants of groundwater are known as stygobites. They provide an important contribution to biodiversity (Sket 1999; Gibert and Culver 
2009), as well as a range of other ecosystem services. These include their role in biogeochemical cycles and contaminant attenuation through their interaction with microbial communities (Boulton et al. 2008; Griebler et al. 2010; Korbel and Hose 2011), their potential as water-quality indicators (Danielopol 1989; Malard et al. 1996; Stein et al. 2010; Hahn 2006), and the information they may provide on past geological and climatic changes and adaptation to unusual environments (Humphreys 2009).

Several studies have demonstrated diverse stygobite communities in the hyporheic zone beneath rivers (e.g., Hancock et al. 2005; Robertson and Wood 2010); in karst caves (e.g., Culver et al. 2003; Knight 2011); in springs (e.g., Halse et al. 2002; Gibson et al. 2008); and within groundwater in carbonate, fractured and granular aquifers (e.g., Hancock and Boulton 2008; Deharveng et al. 2009; Hahn and Fuchs 2009; Galassi et al. 2009). In mainland Britain, there are eight known stygobitic macro-invertebrate species (Proudlove et al. 2003), which are all crustaceans and normally range in size from 1 to $15 \mathrm{~mm}$ in length. Copepoda (another crustacean group which are usually less than $1 \mathrm{~mm}$ in length and are therefore classified as meiofauna) and Oligochaeta (a group of worms) are also commonly present, but have not been investigated to the species level in the UK (Proudlove et al. 2003; Robertson et al. 2009). Recent genetic studies of five UK and Irish stygobitic species of the Niphargus genus have revealed that not only are they endemic lineages, but they are by far the oldest fauna present in the British Isles, having survived millions of years of climate changes in aquifers (McInerney et al. 2014).

Stygobite species diversity in the UK is low compared to other areas of the world where there may be tens of species present within a single aquifer or cave. The low diversity in the UK is thought to be due to local extinctions during glaciations (Proudlove et al. 2003; Robertson et al. 2009); however, the distribution of invertebrate stygobites is not fully known, and groundwater ecosystems represent prime examples of Linnean and Wallacean shortfalls where species diversity and distributions are inadequately characterised (Whittaker et al. 2005). Further understanding of the occurrence and distribution of groundwater invertebrates is needed to address this knowledge gap, and to enable groundwater ecosystem services to be assessed.

The first aim of the study is to use data from a single geological unit to improve understanding of large-scale species distributions. Groundwater habitats are often poorly understood, and it may be difficult to establish whether the occurrence and distribution of invertebrate species are determined by large- or small-scale processes (Malard et al. 2009). Some studies have focused on geographically large areas incorporating a range of geological habitats (e.g., Deharveng et al. 2009). Species richness has been assessed in aquifers classified as karst, porous, and fractured (e.g.,
Hahn and Fuchs 2009); however, a particular aquifer type may incorporate a range of geological strata that form different habitats with specific physical and chemical characteristics (Maurice and Bloomfield 2012). This study investigates boreholes in a single geological unit (the Chalk), in seven different geographical areas, which makes it possible to determine whether geographical variability in species distributions relates to regional factors such as glaciation or limited dispersal, rather than physical or chemical habitat differences that arise due to differences in geology. Previous studies have suggested that stygobite diversity and occurrence is lower in northern than southern England (Proudlove et al. 2003), although non-cavernous groundwater in northern England has not been well studied. The Chalk aquifer outcrops in extensive areas of southeast and northeast England, thereby providing an opportunity to investigate the same habitat in both the north and south of the country.

The Chalk is the most important water supply aquifer in many parts of northern Europe (Downing et al. 2005). Groundwater quality is widely monitored and regulated, and surface groundwater-dependent ecosystems are protected. However, in general, groundwater ecosystems are not considered in water management programs. Nevertheless the Chalk aquifer has been identified as a habitat for invertebrate groundwater fauna in England (Proudlove et al. 2003; Robertson et al. 2009; Sorensen et al. 2013; Johns et al. 2015), and fauna are recorded from Chalk areas in continental Europe (Deharveng et al. 2009; Martin et al. 2009; Michel et al. 2009); however, it is unclear in some of these studies which samples came from the Chalk, and questions remain about where in the aquifer invertebrates occur, and how commonly they occur. The prevalence of species in the Chalk and the importance of the Chalk as an ecological habitat have not been properly assessed. The second aim of this study is to address this by investigating how frequently stygobitic invertebrates occur in the Chalk, and considering how extensive the habitat is; for example, whether it extends to all geographical areas of Chalk outcrop; and whether it extends into areas where water tables are deep beneath the surface, or areas where the chalk is concealed by other strata.

\section{The study aquifer: the English Chalk}

The Chalk is a carbonate aquifer with small-scale surface and subsurface karst (MacDonald et al. 1998; Maurice et al. 2006). High permeability and transmissivity occurs because fractures are solutionally enlarged (Price et al. 1982; Bloomfield 1996) to form fissures (solutional voids that retain the planar geometry of the original fracture), conduits (circular shaped voids), and occasionally caves (voids large enough for humans to enter). These solutional voids form the main habitat for stygobitic invertebrates, although they may also inhabit unmodified 
fractures. The Chalk matrix porosity is $\sim 35 \%$ (Bloomfield et al. 1995), but permeability is very low because the pore throats are very small (Price et al. 1993). Matrix pores are $<3 \mu$ and pore throats are $<1 \mu$ (Hardman 1982); therefore, stygobitic macroinvertebrates are too big to live within the matrix. The Chalk is present in southern and southeast England, East Anglia and easterly areas of northern England (Fig. 1a). The aquifer is heterogeneous and boreholes may intercept varying numbers of permeable voids (Bloomfield 1996). Transmissivity is higher in northern England (Humberside and Lincolnshire) and Dorset than in other areas (Fig 1, Table 1); however, the Chalk has very high transmissivity (1,000's $\mathrm{m}^{2} /$ day) compared to many other rock types (Table 1), and provides a similar habitat for groundwater invertebrates in all areas.

\section{a Antrobathynella stammeri}

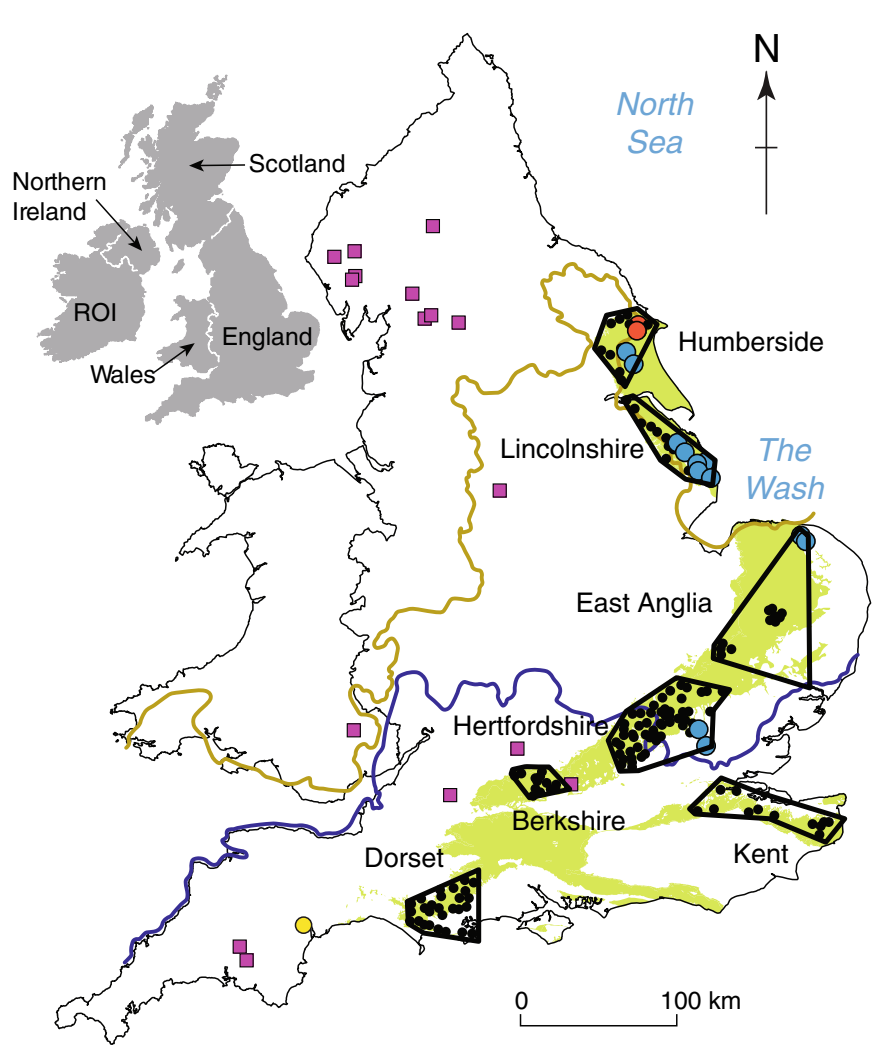

\footnotetext{
Legend

Chalk

Detected

- Not detected (unconcealed chalk)

Not detected (concealed chalk)

$\bigcirc$ Other record (borehole, well)

Other record (cave, river, mine, hyporhesis)

Devensian glacial limit

Anglian glacial limit
}

Fig. 1 Results of borehole invertebrate sampling (circles) in seven Chalk areas. Invertebrates: a Antrobathynella stammeri, b Proasellus cavaticus, c Crangonyx subterraneus, d Microniphargus leruthi, e Niphargus
In some areas, the Chalk is concealed beneath superficial deposits or younger Palaeogene strata. Where there is a substantial thickness of low permeability material overlying the Chalk and preventing direct recharge, the Chalk becomes confined, meaning that the water is under pressure. Confined Chalk has slightly lower permeability than unconfined Chalk (MacDonald and Allen 2001), and very low or absent dissolved oxygen (e.g., Smedley et al. 2003, 2004). This is because it is not well connected to recharge areas and residence times are longer. In this study there are insufficient data to determine whether the Chalk is confined. Boreholes where the Chalk is overlain by low permeability strata and are more than $1 \mathrm{~km}$ from outcrop or overlying permeable deposits, were classified as in "concealed" Chalk, which is likely to be confined.

\section{b Proasellus cavaticus}

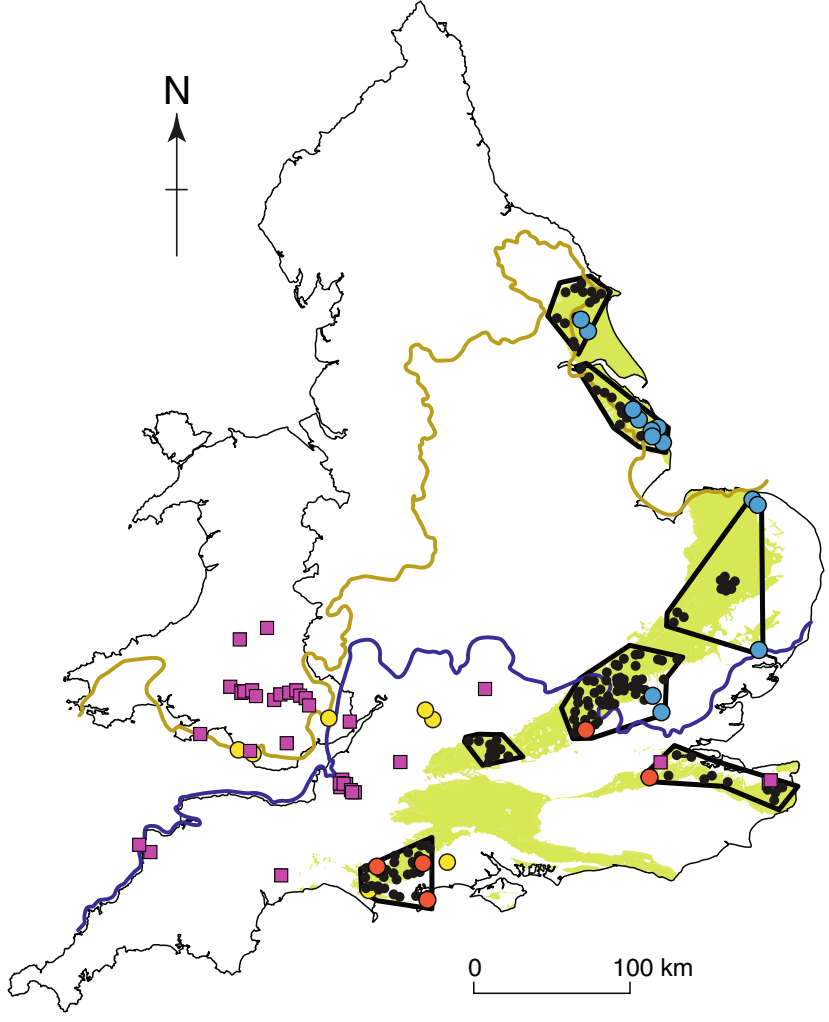

fontanus, f Niphargus kochianus, g Niphargus aquilex, and $\mathbf{h}$ Copepoda. BGS (C) NERC. Contains Ordnance Survey data (C) Crown copyright and database rights 2014 

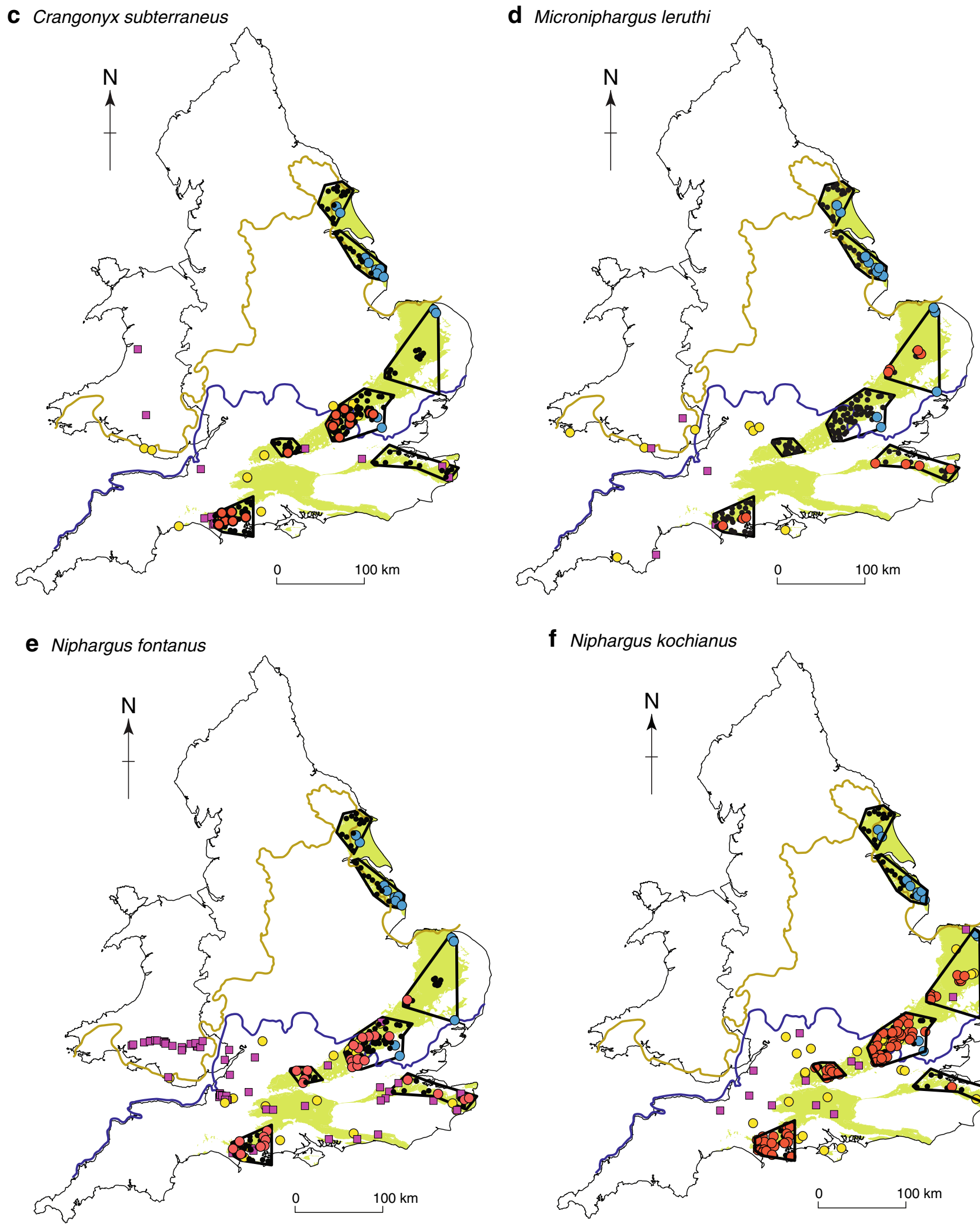

\section{f Niphargus kochianus}

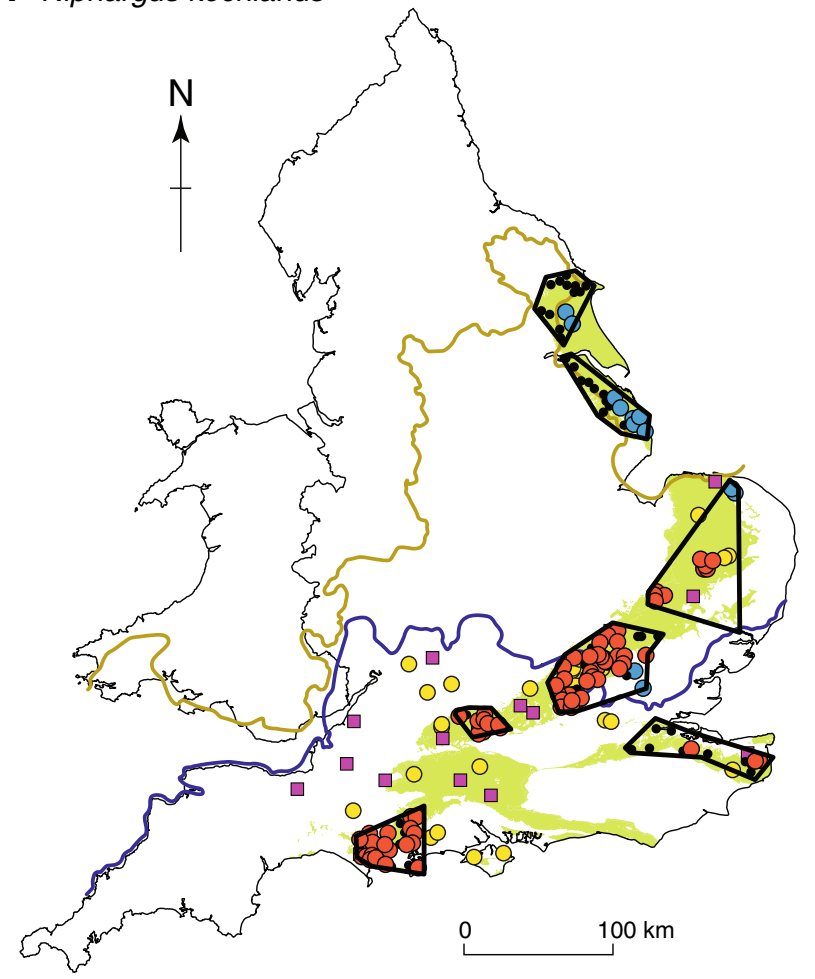

Fig. 1 (continued)

Chalk groundwater chemistry is dominated by high bicarbonate, calcium and $\mathrm{pH}$ and there are no substantial differences between areas (Table 2). The greatest variation is between unconfined and confined chalk: confined groundwater has low or absent oxygen and nitrate, and increased sulphate, chloride and iron. 


\section{g Niphargus aquilex}

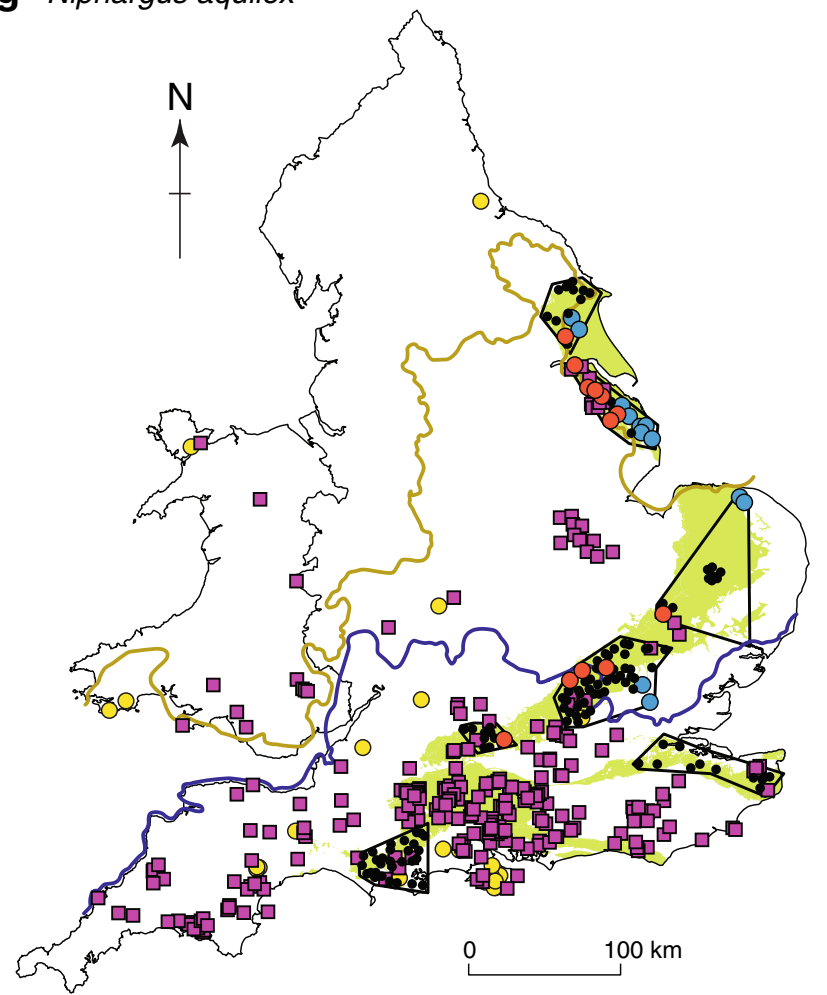

Fig. 1 (continued)

\section{Methods}

\section{A national-scale survey of invertebrate ecology in the Chalk}

Samples were obtained from 198 boreholes distributed across two areas of northern England (Humberside and Lincolnshire) and five areas of southern England (Fig. 1a). Some areas extend slightly into adjacent counties, but are named according to the county where most samples were located. The locations of samples were restricted to existing boreholes, and therefore it was not feasible to implement a randomized statistical design or to fully control factors such as the depth and diameter of each borehole. Most sampled boreholes are unpumped closed monitoring boreholes, and sites were selected on the basis of ease of access and permission to sample. Sixteen boreholes were sampled in Berkshire, East Anglia, Humberside, and Lincolnshire between 2009 and 2011, and 13 were sampled in Kent in 2011. In these areas sample distributions were determined by the availability of boreholes with the following criteria: not being pumped, only containing equipment that could be easily removed, less than $120 \mathrm{~m}$ deep, between 50 and $300 \mathrm{~mm}$ in diameter, with an uncased section open only to the Chalk. Thirty-one unpumped boreholes were sampled in Dorset in 2009 (Johns et al. 2015), and 40 unpumped and 50 pumped boreholes were sampled in Hertfordshire between 2003 and 2009. h Copepoda

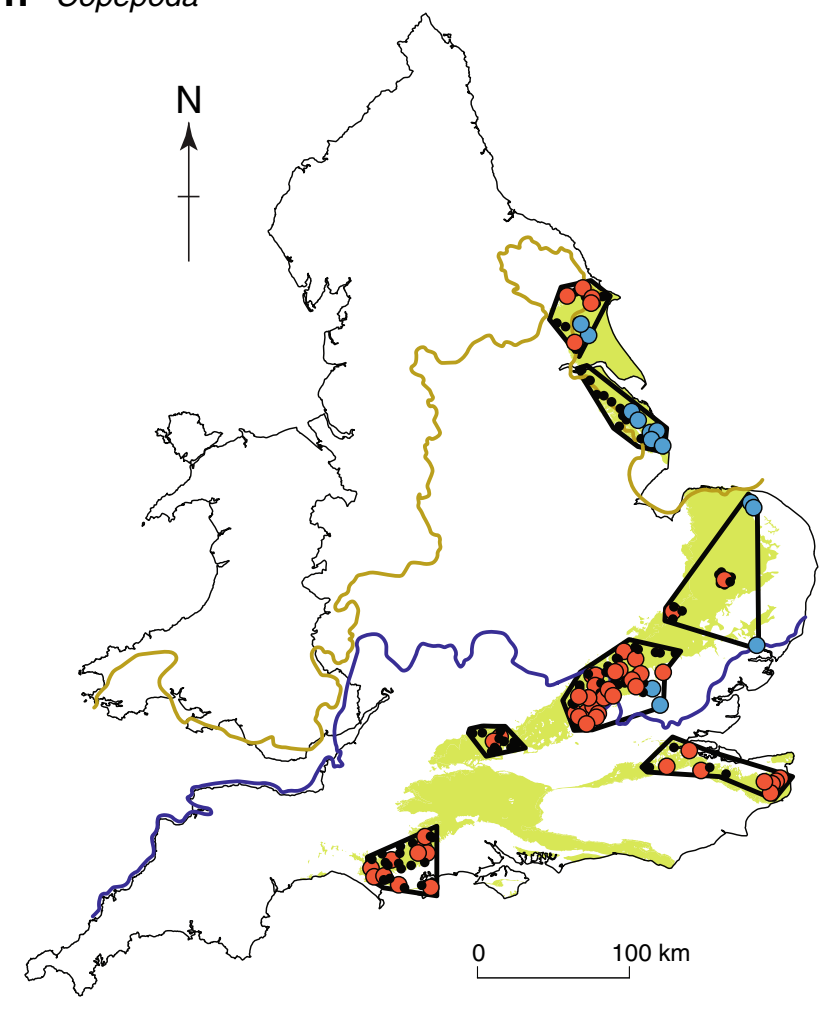

The mean and range of borehole depths, diameters, and water levels in each area are presented in Table 3. Water levels and borehole depths were fairly similar in all areas, whilst diameters were more variable, and included some much larger diameter sites in Dorset and Hertfordshire.

Sampling was undertaken using a weighted borehole net with a $63-\mu$ mesh and filter, and each borehole was sampled on a single occasion. Net diameters varied from 3 to $30 \mathrm{~cm}$, depending on the diameter of the borehole. The net was connected to a cord and lowered to the bottom of the borehole three times to disturb sediment and then brought to the surface where sediment and fauna were collected and stored in $>96 \%$ ethanol. This net sampling method collects an integrated sample comprising the sediment from the bottom and any invertebrates collected from other depths as the net is hauled up the borehole. Three net samples were collected at each site, except in Hertfordshire where only 1 or 2 net samples were collected; and at some Hertfordshire sites baited traps were used in addition to nets. Fifty of the Hertfordshire boreholes are actively pumped for water supply. Because of these differences in the Hertfordshire boreholes, the results are only used for descriptive purposes, and they were excluding from the statistical analyses.

In the laboratory, fauna were separated from sediment and identified using a stereoscopic microscope. A compound microscope was also used to examine further deterministic features on juvenile and damaged specimens, and for the identification of Antrobathynella stammeri and some 
Table 1 Transmissivity $(T)$ in the study areas with other UK data for comparison (compiled from Allen et al. 1997 and Jones et al. 2000)

\begin{tabular}{llll}
\hline & No. records & Average $T\left(\mathrm{~m}^{2} /\right.$ day $)$ & Median $T\left(\mathrm{~m}^{2} /\right.$ day $)$ \\
\hline Study area & & & \\
Dorset & 24 & 1,872 & 1,800 \\
Berkshire & 39 & 1,073 & 970 \\
Kent & 51 & 1,074 & 600 \\
Hertfordshire & 42 & 1,005 & 580 \\
Humberside & 40 & 3,223 & 1,700 \\
Lincolnshire & 57 & 2,060 & 1,800 \\
East Anglia & 335 & 1,203 & 430 \\
UK data & & & \\
Chalk (all) & 1,195 & 1,281 & 530 \\
Jurassic limestones & 156 & 1,537 & 565 \\
Magnesian limestone & 80 & 556 & 210 \\
Permo-Triassic sandstones & 690 & 412 & 210 \\
Igneous aquifers & 18 & 12.7 & 4.2 \\
Devonian arenaceous rocks & 22 & 9.1 & 4 \\
Devonian argillaceous rocks & 72 & 10.7 & 3.3 \\
Mercia mudstone formation & 149 & 126 & 17.5 \\
Upper greensand formation & 57 & 276 & 100 \\
\hline
\end{tabular}

Microniphargus leruthi specimens. Samples with substantial sediment were sieved to separate different sized particles enabling fauna to be picked out more easily. Stygobitic macroinvertebrates were identified to the species level using Gledhill et al. (1993) and Knight and Gledhill (2010). Copepoda were not identified to the species level, and therefore it is not possible to know if they are stygoxenes (surface species that accidentally entered groundwater), stygophylic (able to live in both surface and subsurface environments), or stygobitic (restricted to the subsurface).

\section{Investigating regional-scale patterns in species distributions}

The analyses are largely descriptive since the borehole locations could not be selected according to a statistical design, and the Hertfordshire boreholes have been excluded due to inconsistencies in the sampling method. The study is focused on the locations and the conditions in which the different species were observed. The variation in borehole properties such as depth, diameter, water level, length of uncased saturated section within the borehole, and distance to nearest watercourse could influence the results. It was not possible to produce robust models of the effect of each of these properties since these components of variation were confounded with spatial variation. The significance of each of the estimated parameters of such models was overly sensitive to the type of relationship that was assumed; therefore, a non-parametric method was used to explore these relationships. For each borehole property, the boreholes were divided into ten equally sized groups according to the value of the property and then the proportion of wells where each species occurred was compared for each group.

In some instances, specific species were absent from the boreholes in northern England but present in southern England. The significance of these absences was tested by fitting generalized linear models (GLM; Dobson 2001) to the data from the southern boreholes (excluding the Hertfordshire boreholes) and then using these models to predict the probability of not observing this species in any of the northern boreholes. Due to the non-random nature of the sample design these tests can only give an indication of the significance of our findings.

In each estimated GLM the occurrence of a species at borehole $i$ is assumed to be a realization of a Bernoulli distribution and the canonical logit link function is applied so that the probability $p_{i}$ of occurrence is (Dobson 2001):

$\mathbf{p}=\frac{1}{1+\exp (-\mathbf{X} \boldsymbol{\beta})}$

Where $\mathbf{p}$ is a length $n$ vector containing the $p_{i}$ values for each borehole, $\mathbf{X}$ is a $n \times q$ matrix containing the value of $q$ covariates or properties for each borehole and $\beta$ is a vector of $q$ coefficients. The models were estimated using a stepwise regression algorithm (MATLAB function stepwiseglm). This algorithm estimates a series of models by maximum likelihood. In the initial version of the model, $\mathbf{X}$ is a vector of ones and, hence, the $p_{i}$ values are identical. Then each of the borehole properties is added to the model in turn and the one which causes the biggest increase to the likelihood is selected. If a 
likelihood ratio test demonstrates that the increase to the likelihood is significant, then this property is added to the model and the procedure continues to test whether further properties should be added. If at any point none of the unused properties lead to a significant increase in the likelihood, then the model fitting halts. Finally, the estimated models were used to simulate 100,000 realizations of the presence/absence of the species at each of the boreholes in the north of England. If, for example, fewer than 1,000 of these realizations contained no occurrences at any of the boreholes then the observed absence in the north is statistically significant at the $p=0.01$ level. The $p=0.01$ level of significance was adopted for these tests rather than the more standard $p=0.05$ level to account for the possibility of false rejections of the null hypothesis amongst the multiple tests (Benjamini and Hochberg 1995).

\section{Investigating the importance of the Chalk aquifer habitat}

\section{The extent of the habitat}

It was anticipated that the Chalk habitat for stygobitic invertebrates does not extend into the confined Chalk, but to investigate this, 14 boreholes were sampled from the concealed Chalk. To investigate the vertical extent of the habitat, boreholes from the unconcealed Chalk were grouped into those with water tables at $<5 \mathrm{~m}$ below the surface, 5-50 m below the surface, and $>50 \mathrm{~m}$ below the surface. For each category, the number of boreholes in which each species was found was recorded. Species found in boreholes with water tables $>50 \mathrm{~m}$ must have originated from deep habitats $>50 \mathrm{~m}$ below the surface.

\section{Invertebrate abundance}

The numbers of invertebrates collected at each sampling site provide some information on their abundance in boreholes. However, it is not clear what proportion of individuals living in the borehole are collected in a sample comprising three net hauls. If there is a decline in numbers in later net samples, it might suggest that a large proportion of invertebrates present within the borehole have been collected in the three net hauls. To investigate this, at 77 of the 198 sample sites, the three individual net hauls were collected and analysed separately enabling the numbers of stygobitic amphipods from the individual nets to be counted. Kruskal-Wallis one-way analysis of variance on ranks was used to test for differences in numbers of amphipods collected in the three net hauls. Additional sampling (not included in the main analysis) was undertaken at two boreholes in Berkshire (Calversley Farm and Brightwalton Common), where ten or more net hauls were carried out to provide further information on the number of invertebrates present in boreholes. 
Table 3 Mean and range of borehole parameters in sampling areas

\begin{tabular}{lllll}
\hline & No. boreholes & Depth $(\mathrm{m} \mathrm{bgl})$ & Diameter $(\mathrm{m})$ & Water level $(\mathrm{m}$ bgl) \\
\hline Berkshire & 16 & $68.1(26.9-115.0)$ & $0.28(0.20-0.30)$ & $36.2(0.7-79.3)$ \\
Kent & 13 & $82.2(21.5-147.6)$ & $0.31(0.15-0.83)$ & $43.3(6.55-105)$ \\
East Anglia & 16 & $62.9(31.5-113.5)$ & $0.16(0.15-0.23)$ & $15.9(1.9-60.7)$ \\
Humberside & 16 & $54.3(22.1-105.6)$ & $0.22(0.15-0.53)$ & $32.7(0.9-88.6)$ \\
Lincolnshire & 16 & $64.9(35.9-101.9)$ & $0.13(0.09-0.15)$ & $27.3(1.9-64.6)$ \\
Dorset & 31 & $46.17(4.5-130.0)$ & $0.36(0.05-2.0)$ & $16.5(0.8-75.6)$ \\
Hertfordshire & 90 & $79.4(8.0-186.5)$ & $0.94(0.02-3.0)$ & $16.7(0.3-69.3)$ \\
\hline
\end{tabular}

$b g l$ below ground level
Faunal abundance in boreholes is not necessarily representative of abundance in the aquifer as boreholes are good habitats that tend to accumulate invertebrates (Hahn and Matzke 2005; Sorensen et al. 2013). To investigate the pervasiveness of particular species in the Chalk aquifer, the percentage of boreholes sampled which contained each species was calculated.

\section{Results}

\section{Regional-scale invertebrate distributions in the Chalk}

Seven stygobite species were identified, and Copepoda were also commonly found (Figs. 1a-h and 2, Table 4). The syncarid Antrobathynella stammeri (Jakobi 1954) was only found in Humberside, and these are the first records in this area of northeast England (Fig. 1a). The isopod Proasellus cavaticus (Leydig, 1871 sensu Henry, 1970) was found in Dorset, Hertfordshire and Kent (Fig. 1b). However, most of the stygobites found were amphipods. Crangonyx subterraneus (Bate, 1859) was present in Dorset, Berkshire and Hertfordshire (Fig. 1c). Records of Microniphargus leruthi (Schellenberg, 1934) in Dorset were the first in the Chalk and amongst the first in mainland Britain (Knight and Gledhill 2010), and it was subsequently found in Kent, East Anglia and Berkshire (Fig. 1d). Niphargus kochianus (Bate, 1859) and Niphargus fontanus (Bate, 1859) were found in all areas except Lincolnshire and Humberside (Fig. 1e,f), and the known range of $N$. fontanus has been extended slightly north and east into East Anglia. Niphargus aquilex (Schiödte, 1855) was recorded in all regions except Kent and Dorset (Fig. 1g), although this species is known to occur within both these areas. Copepoda were found in all areas except Lincolnshire (Fig. 1h).

Few obvious relationships between the borehole properties and the occurrence of different species were observed (Fig. 3) - for example, Fig. 3b shows how the proportion of boreholes where $N$. kochianus was recorded varies irregularly with the borehole depth, diameter, and water level. The variation is also irregular for Copepoda (Fig. 3h) although they are observed in a large proportion of the large diameter boreholes.
The only patterns of note amongst the remaining species are that $C$. subterraneus is only observed in boreholes of depth less than $10.3 \mathrm{~m}$ and water level less than $0.75 \mathrm{~m}$ (Fig. 3e), and $N$. aquilex was not observed in shallow boreholes or boreholes with shallow water levels.

According to the GLMs of $N$. kochianus and $N$. fontanus fitted to the borehole records from southern England, the absence of these species in the boreholes from northern England was significant at the $p=0.01$ level. Figure 4 shows that when the models fitted to the southern boreholes were used to simulate 100,000 realizations of the occurrences/absences in the northern boreholes, there were fewer than 1,000 realizations where the species was completely absent. However, $M$. leruthi, C. subterraneus and P. cavaticus were less prevalent in southern England, and their absence from the boreholes sampled in northern England proved not to be significant at this level ( $p$-values $0.02,0.08$ and 0.26 respectively). Therefore, more boreholes would need to be sampled in northern England to determine whether these species are truly absent. In the GLMs, none of the recorded borehole properties (depth, diameter, water level, distance to nearest watercourse) proved to be a significant predictor of species presence-absence except when the model of C. subterraneus included distance to nearest watercourse and water level.

\section{The importance of the Chalk habitat}

\section{The extent of the habitat}

No invertebrate fauna were found in any of the 13 boreholes in the concealed Chalk. In the unconcealed Chalk, six of the seven macro-invertebrate species and Copepoda were found in boreholes with water levels $>50 \mathrm{~m}$ below the surface, demonstrating that the habitat extends to substantial depths beneath the surface (Table 5). With the exception of N. aquilex and A. Stammeri, all macro-invertebrate species and Copepoda were found in boreholes less than $21 \mathrm{~m}$ deep (decile 1 in Fig. 3), suggesting that they can also inhabit fairly shallow groundwater. 
Fig. 2 Species present in the Chalk. Pictures by a Chris Procter, b,c,e Lee Knight, d Mark Dunscombe, f Francois Edwards, and $\mathbf{g}$ Jules Carter. Organisms range in length from ca. $0.5 \mathrm{~mm}$ to ca. $10 \mathrm{~mm}$
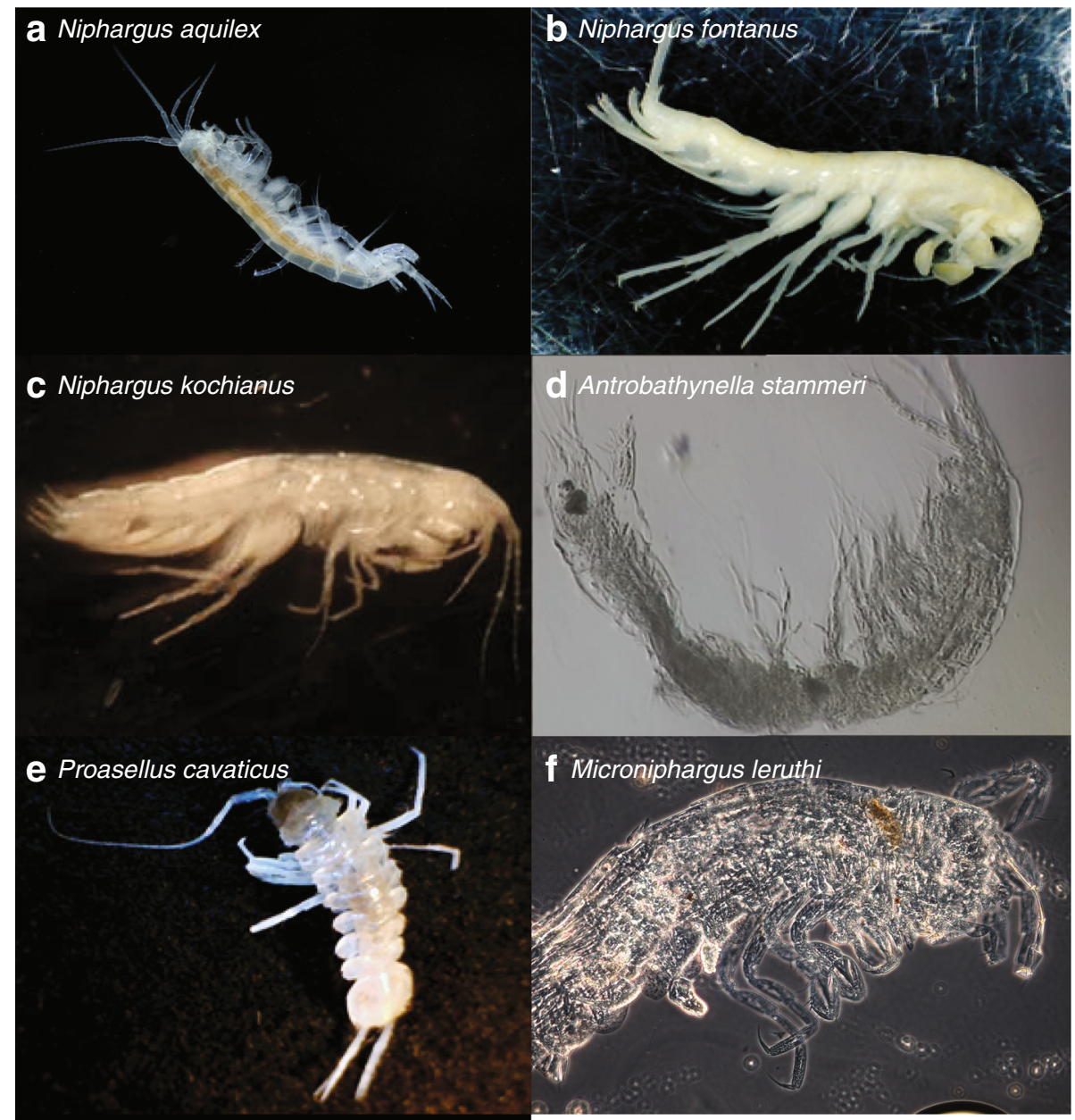

g Crangonyx subterraneus

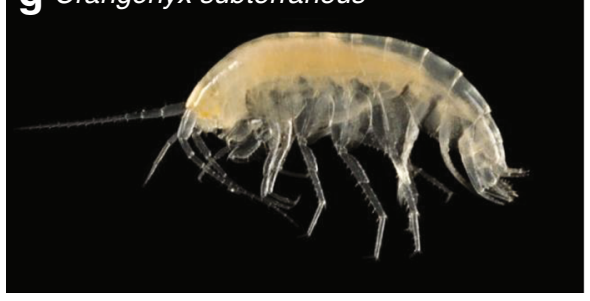

Invertebrate species occurrence and abundance in the unconcealed Chalk aquifer

A high proportion of boreholes in the unconcealed Chalk (67\%) contained stygobitic invertebrates. In southern England, the overall proportion was $77 \%$, and ranged from 68 to $92 \%$ in the different areas (Table 4). In northern England, a smaller proportion of boreholes contained stygobites (38\%). Most boreholes contained amphipods, whilst a small number contained only the isopod $P$. cavaticus or the syncarid A. stammeri. In southern England, $N$. kochianus was by far the dominant species (Table 4), both in terms of the number of boreholes where it was present (62\% of unconcealed boreholes sampled), and the numbers of individuals collected within these boreholes, which ranged from an average of 9 in Dorset to 28 in Kent (Table 4). At sites in southern England where samples consisted of three net hauls, $779 N$. kochianus were collected from 45 boreholes, equating to an average of 17 per borehole.

Other stygobitic species were present in a smaller proportion of boreholes, and in smaller numbers (Table 4). Niphargus aquilexappears present in a greater proportion of boreholes, and in higher numbers in Lincolnshire than in other areas of the UK. Copepoda were also present in a high proportion of boreholes (Table 4, Fig. 1h), and where they occurred, they were often more abundant than other groups, with tens or even hundreds of individuals collected from three net hauls within a borehole. 
Table 4 Regional summary of invertebrates in the unconcealed Chalk

\begin{tabular}{|c|c|c|c|c|c|c|c|c|c|}
\hline & \multicolumn{3}{|c|}{ Northern England } & \multicolumn{6}{|c|}{ Southern England } \\
\hline & Humberside & Lincolnshire & $\begin{array}{l}\text { All N } \\
\text { England }\end{array}$ & $\begin{array}{l}\text { East } \\
\text { Anglia }\end{array}$ & Kent & Berkshire & Dorset & $\begin{array}{l}\text { S England (excluding } \\
\text { Hertfordshire) }\end{array}$ & Hertfordshire $^{\mathrm{a}}$ \\
\hline Size of area $\left(\mathrm{km}^{2}\right)$ & 692 & 675 & 1,367 & 3,500 & 1,271 & 247 & 1,056 & 6,074 & 2,460 \\
\hline Total boreholes & 16 & 16 & 32 & 16 & 13 & 16 & 31 & 76 & 90 \\
\hline $\begin{array}{l}\text { No. boreholes in unconcealed } \\
\text { Chalk }\end{array}$ & 14 & 10 & 24 & 13 & 13 & 16 & 31 & 73 & 88 \\
\hline$\%$ boreholes with stygobites & 21 & 60 & 38 & 92 & 69 & 88 & 68 & 77 & 70 \\
\hline$\%$ boreholes with amphipods & 7 & 60 & 29 & 92 & 69 & 88 & 68 & 77 & 69 \\
\hline$\%$ boreholes with copepods & 29 & 0 & 17 & 15 & 62 & 13 & 32 & 30 & 48 \\
\hline$\%$ boreholes with $N$. kochianus & 0 & 0 & 0 & 77 & 31 & 75 & 61 & 62 & 68 \\
\hline$\%$ boreholes with $N$. aquilex & 7 & 60 & 29 & 8 & 0 & 13 & 0 & 4 & 3 \\
\hline$\%$ boreholes with $N$. fontanus & 0 & 0 & 0 & 8 & 38 & 31 & 29 & 27 & 25 \\
\hline$\%$ boreholes with $C$. subterraneus & 0 & 0 & 0 & 0 & 0 & 13 & 23 & 13 & 18 \\
\hline$\%$ boreholes $M$. leruthi & 0 & 0 & 0 & 31 & 31 & 0 & 10 & 15 & 0 \\
\hline$\%$ boreholes with $P$. cavaticus & 0 & 0 & 0 & 0 & 8 & 0 & 10 & 6 & 1 \\
\hline$\%$ boreholes with $A$. stammeri & 14 & 0 & 1 & 0 & 0 & 0 & 0 & 0 & 0 \\
\hline No. N. kochianus & 0 & 0 & 0 & 180 & 113 & 310 & 176 & 779 & 1,116 \\
\hline No. N. aquilex & 2 & 46 & 48 & 4 & 0 & 2 & 0 & 6 & 3 \\
\hline No. N. fontanus & 0 & 0 & 0 & 1 & 12 & 6 & 15 & 34 & 49 \\
\hline No. C. subterraneus & 0 & 0 & 0 & 0 & 0 & 2 & 34 & 36 & 109 \\
\hline No. M. leruthi & 0 & 0 & 0 & 9 & 14 & 0 & 4 & 27 & 0 \\
\hline No. P. cavaticus & 0 & 0 & 0 & 0 & 8 & 0 & 8 & 16 & 1 \\
\hline No. A. stammeri & 27 & 0 & 27 & 0 & 0 & 0 & 0 & 0 & 0 \\
\hline No. copepods & 403 & 0 & 403 & 29 & 855 & 62 & 407 & 1,353 & 549 \\
\hline No. stygobite species & 2 & 1 & 2 & 4 & 4 & 4 & 5 & 6 & 5 \\
\hline $\begin{array}{l}\text { Mean No. } N \text {. kochianus per } \\
\text { borehole where it was present }\end{array}$ & 0 & 0 & 0 & 18 & 28 & 26 & 9 & 17 & 19 \\
\hline
\end{tabular}

${ }^{\text {a }}$ Samples comprise 1-2 net hauls and specimens collected from baited traps, 50 boreholes pumped for abstraction

\section{Borehole abundance}

Of the 77 boreholes in which the three different net samples were analysed separately, 42 contained stygobitic amphipods. In these boreholes, the mean number collected declined from 6.1 in net one to 4.9 in net two to 3.0 in net three. KruskalWallis one-way analysis of variance on ranks indicates that there is a significant reduction in the number of amphipods between net one and net three $(p=0.027)$.

Niphargids were the only invertebrates collected in the multiple net samples obtained from the Brightwalton Common and Calversley boreholes. At Brightwalton Common there were similar numbers present in 12 net samples (Fig. 5). There is no apparent decline in the numbers, suggesting that even after 12 net hauls there were more invertebrates present in the borehole. At Calversley, ten samples were collected on 15/03/10 with an apparent decline in niphargid numbers in later samples, although some individuals were still present in the final net sample (Fig. 5). Three net samples the following day (16/03/10) captured a similar number of niphargids as the first three samples collected on $15 / 03 / 10$. Overall, the numbers of invertebrates collected in three net hauls are likely to represent a low estimate of the borehole abundance.

\section{Discussion}

\section{Regional-scale patterns in stygobite species distributions}

The survey of the Chalk was limited to existing boreholes and it was not possible to completely control the properties (e.g., diameter, depth, water level) of each borehole; therefore, the results are primarily descriptive. Where the significance of the absence of particular species in northern England was tested, caveats apply because of the non-statistical nature of the sample design. However, given the absence of obvious relationships between the measured borehole properties and the occurrence of each species, it is likely that the results reflect differences in the invertebrate populations and habitats. 
Fig. 3 Relationships between the proportion of samples where a $N$. aquilex, b $N$. kochianus, $\mathbf{c} M$. leruthi, $\mathbf{d} N$. fontanus, e $C$. Subterraneus, f $A$. stammeri, $\mathbf{g} P$. cavaticus and $\mathbf{h}$ Copepoda are observed and the decile of borehole depth, diameter and water level
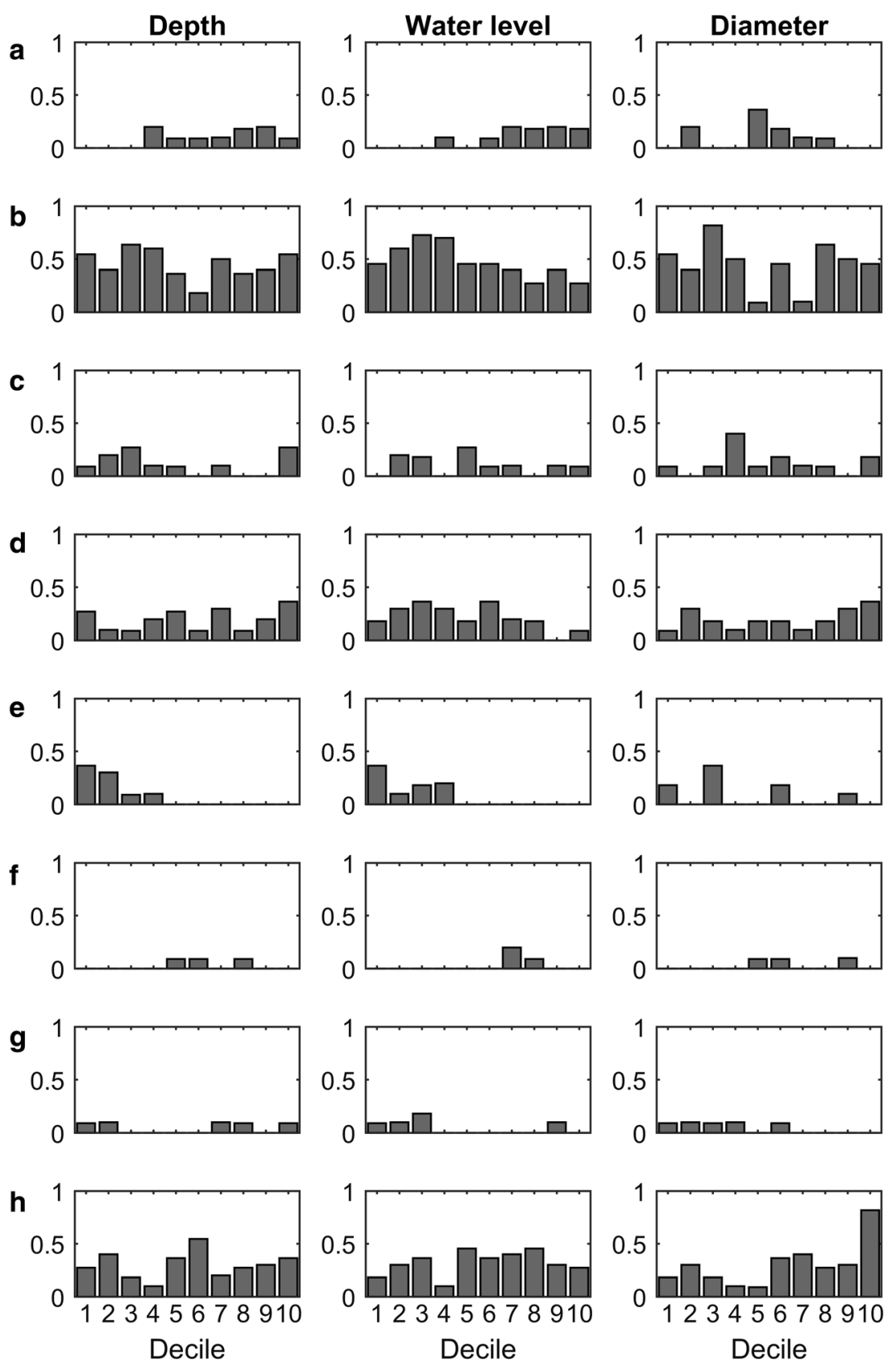

Because the unconfined Chalk aquifer provides a suitable habitat in all areas, the absence of a species within an area either indicates it is rare in Chalk boreholes, or the geographical range of the species does not extend into the area.

Two species (N. kochianus and $N$. fontanus) were present in a high proportion of boreholes in southern England and their absences from sampled boreholes in northern England were statistically significant. There are no previous records of these species in northern England and these findings are likely to reflect a true absence (Fig. 1e,f). Either these species have never dispersed to these areas, or they were present but did not survive the Pleistocene glaciations. The estimated Devensian glacial limit passes through the northern England Chalk sampling area, which would have been fully glaciated during the earlier, more extensive Anglian glaciation. Genetic studies have shown that the UK populations of $N$. kochianus and $N$. fontanus are ancient cryptic endemic lineages that have been in the UK at least since they separated from their nearest ancestor in continental Europe about 2.9 and 0.8 million years ago respectively (McInerney et al. 2014). The Chalk outcrop is continuous under the North Sea, and the Wash (see Fig. 1a) was only formed at the end of the Devensian glaciation, 12,000 years ago. Prior to this, there would have been a continuous Chalk habitat between East Anglia and Lincolnshire. It 

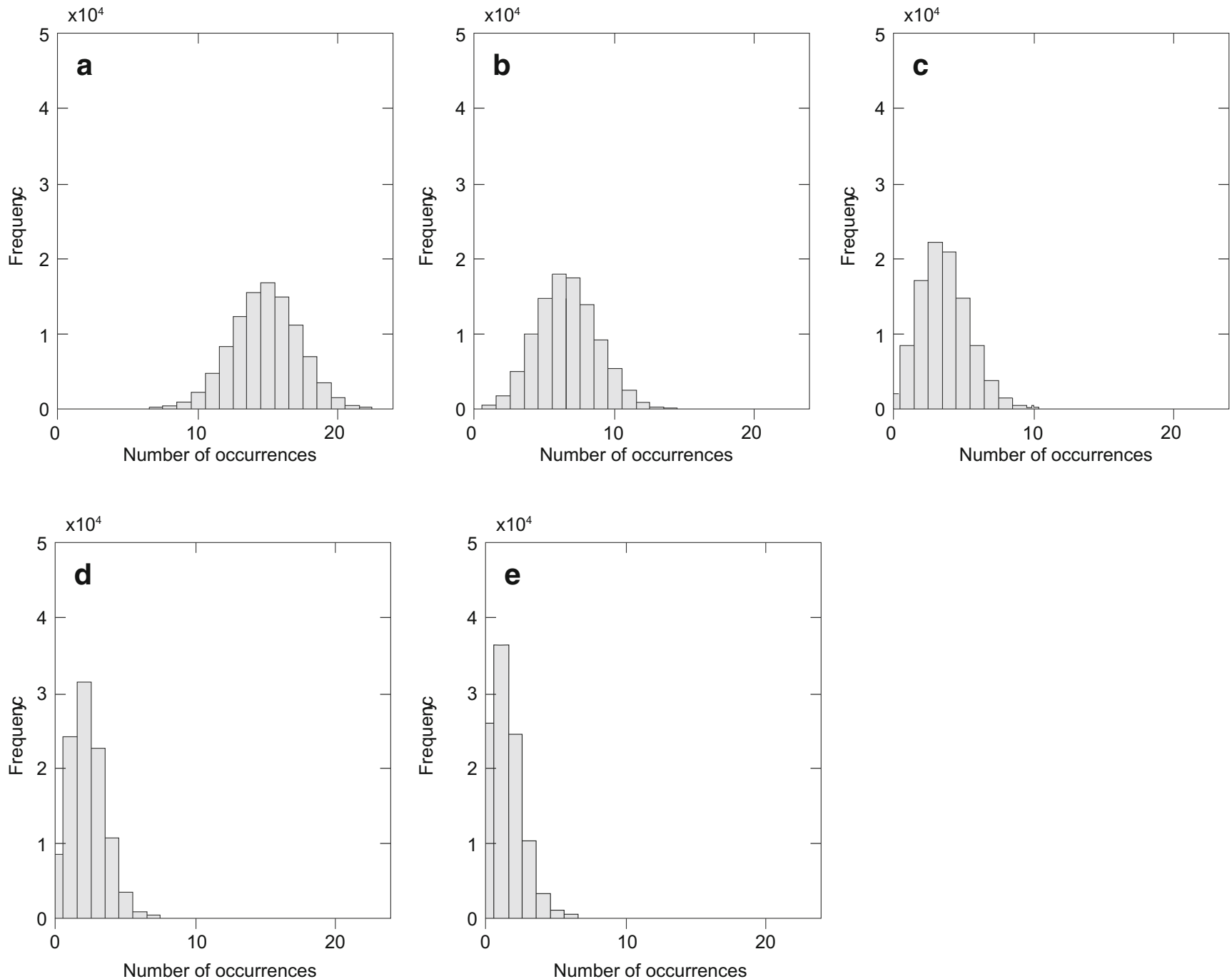

Fig. 4 Number of boreholes in the north of England where a N. kochianus, b $N$. fontanus, $\mathbf{c}$ M. leruthi, $\mathbf{d}$ C. subterraneus and $\mathbf{e}$ P. cavaticus occurred for each of the 100,000 simulations based on the model of occurrences in the south of England

therefore seems possible that $N$. kochianus and $N$. fontanus might have once been present in northern England, and have been eradicated during glaciations. The creation of the Wash separating the southern and northern Chalk has made it impossible for these species to recolonize the northern England Chalk from the East Anglia Chalk because there is no continuous habitat. It is possible that they could recolonize these areas via other geologies to the west; however, low
Table 5 Numbers of unconcealed Chalk boreholes with different water-table depths which contained stygobitic macro-invertebrate species or Copepoda

\begin{tabular}{lllll}
\hline & Water table $<5 \mathrm{~m}$ & Water table $5-50 \mathrm{~m}$ & Water table $>50 \mathrm{~m}$ & Total \\
\hline Total boreholes & 48 & 112 & 25 & 185 \\
N. aquilex & 0 & 8 & 5 & 13 \\
N. kochianus & 29 & 67 & 9 & 105 \\
M. leruthi & 2 & 7 & 2 & 11 \\
N. fontanus & 9 & 31 & 2 & 42 \\
C. subterraneus & 10 & 14 & 1 & 25 \\
A. stammeri & 0 & 2 & 0 & 2 \\
P. cavaticus & 2 & 2 & 1 & 5 \\
Copepoda & 23 & 40 & 6 & 69 \\
\hline
\end{tabular}




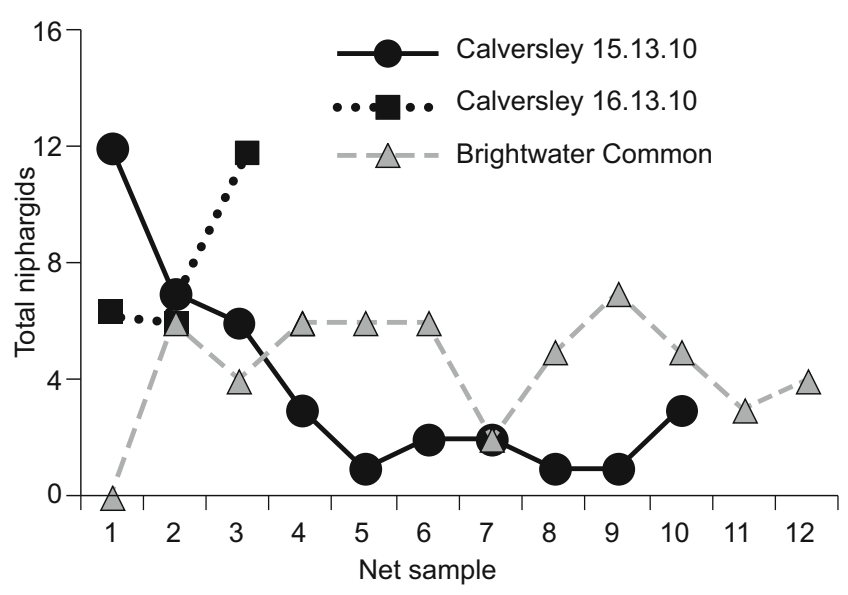

Fig. 5 Multiple net hauls in two boreholes in Berkshire

permeability mudstones, that are unlikely to provide a good habitat, occur to the west of the Chalk. Permeable superficial deposits or hyporheic zone corridors could provide dispersal corridors as suggested by Ward and Palmer (1994) for meiofauna; however, $N$. kochianus has not been found in UK hyporheic zones, and appears not be suited to this type of habitat (Proudlove et al. 2003). Niphargus kochianus and N. fontanus are present to the north of the Anglian glacial limit (Fig. 1f), suggesting that either they survived this glaciation in refugia, or they have recolonized this area during the 424,000 years since the end of the Anglian glaciation.

Other species distributions do extend into northern England Chalk (N. aquilex, A. stammeri), and must either have survived glaciations in refugia, or have dispersed to these areas since they were deglaciated (Proudlove et al. 2003). The genetic study by McInerney et al. (2014) showed that $N$. aquilex specimens from the Chalk in northern England are part of an endemic cryptic lineage that diverged from the continent about 1 million years ago; therefore, this lineage predates both the Anglian and Devensian glaciations. Niphargus aquilex is commonly found in the hyporheic zone and shallow habitats (Proudlove et al. 2003; and more recent data in the UK Hypogean Crustacea Recording Scheme database), and therefore may be able to utilise hyporheic zone dispersal corridors and superficial deposits. Other species that were not found in northern England were only found in a small proportion of Chalk boreholes in southern England (C. subterraneus, P. cavaticus, and M. leruthi). The absence of these species in the northern boreholes was not statistically significant and more boreholes would have to be sampled to demonstrate a difference between the occurrences in the north and south of England.

$N$. aquilex was not found in Kent or Dorset despite previous records of this species in these areas (Fig. 1g). This is likely to be because of the low numbers of $N$. aquilex in Chalk boreholes, compared to other habitats where it is commonly found. The absence of $N$. aquilex in most Chalk boreholes in southern England supports previous suggestions that this species occupies shallow habitats (Proudlove et al. 2003); however, in the six (out of 161) boreholes in unconcealed Chalk in southern England where it was present, water levels ranged from 12 to $77 \mathrm{~m}$ below the ground surface, indicating that the species can also occur in deep groundwater; and as shown in Fig. 3a, N. aquilex was not found in shallow boreholes in this study. It is unclear why $N$. aquilex appears more common in the northern England unconcealed Chalk, where it was present in seven out of 24 boreholes which had a mean water level $48.4 \mathrm{~m}$ below the surface.

\section{The importance of the Chalk as an ecological habitat}

There were no invertebrates captured in any of the 13 boreholes that are classified as concealed and are likely to be in confined Chalk. Although this is only a small number of sites, it is quite likely that stygobitic invertebrates are generally absent from the confined Chalk, because dissolved oxygen is absent or very low. This is as a consequence of little water circulation and long water residence times, which may be up to thousands of years in deeply confined areas (Smith et al. 1976). Although stygobites have been found in a wide range of dissolved oxygen conditions (Boulton et al. 1992), and they have been shown to be more resistant to anoxia than surface water invertebrates, they do not appear to be able to survive in such conditions indefinitely (Malard and Hervant 1999), and studies have demonstrated that stygobitic species require welloxygenated waters (e.g., Dole-Olivier et al. 2009).

This study shows that stygobitic invertebrates inhabit both shallow and deep groundwater environments in the unconcealed Chalk aquifer. Hydrogeological investigations have demonstrated water circulation extending to $50 \mathrm{~m}$ below the water table (Price 1987; MacDonald and Allen 2001; Schurch and Buckely 2002) with oxygenated waters (Edmunds et al. 2003); and solutional fissures have been observed up to $80 \mathrm{~m}$ (Maurice et al. 2012). Targeted sampling of individual fissures using inflatable packers to isolate them has revealed that stygobitic invertebrates are present in fissures up to $98 \mathrm{~m}$ below the surface in the Chalk aquifer (Sorensen et al. 2013). The unconcealed Chalk therefore provides a vertically as well as laterally extensive habitat for invertebrates.

Estimating invertebrate abundance in aquifers is difficult because invertebrates tend to be concentrated within boreholes (Hahn and Matzke 2005; Eberhard et al. 2009; Sorensen et al. 2013). It is impossible to relate the numbers of invertebrates collected from borehole net samples to the number present in the aquifer because it is uncertain how long they have been in the borehole, and how many different fissures contributed invertebrates. Large numbers collected in net hauls may reflect high numbers in the aquifer, or may occur because individuals have been in the borehole for a long time and accumulated or reproduced. The proportion of 
boreholes in which a species is found is perhaps a better indication of the species prevalence in the aquifer. Given that individual boreholes are just point samples in a potentially extensive habitat, and that previous studies (in other geologies) have suggested that multiple sampling occasions are often required to detect species in boreholes (Allford et al. 2008; Eberhard et al. 2009; Hancock and Boulton 2009), it is remarkable that $67 \%$ of our borehole samples detected stygobitic invertebrates on just a single sampling occasion. It is clear that the Chalk represents an important and widespread habitat for groundwater adapted invertebrates in England, and is likely to do so throughout Europe, where similar hydrogeological conditions exist (Downing et al. 2005), and fauna have been previously recorded (Deharveng et al. 2009; Martin et al. 2009; Michel et al. 2009).

Niphargus kochianus is the most abundant stygobitic invertebrate species in Chalk boreholes with between 9 and 28 individuals captured per borehole in southern England (Table 4, Fig. 1e). Where present, Copepoda occurred in even greater numbers (Table 4). Niphargus kochianus and Copepoda appear well suited to the Chalk borehole environment, and high numbers may reflect reproduction within the borehole. However, they are also found in a high proportion of boreholes, indicating that they are likely to be common within the aquifer. It has been suggested that stygobitic invertebrates may be useful indicators of groundwater quality (Stein et al. 2010); however, one difficulty is that many species are sparsely distributed within aquifers. Niphargus kochianus is unusual because it is widespread in Chalk boreholes in southern England, and might therefore be a good water quality indicator, although studies would be needed to determine its ecological optima and tolerance ranges with respect to specific physical and chemical variables.

Other stygobitic species ( $N$. aquilex, $N$. fontanus, $C$. subterraneus, $P$. cavaticus, A. stammeri, $M$. leruthi) occurred in much lower numbers. There were generally only $1-3$ individuals collected from boreholes where they were present. Despite this, $N$. fontanus occurred in a reasonably high proportion of boreholes in southern England, suggesting that it may be fairly widespread in the aquifer. Crangonyx subterraneus, $P$. cavaticus and $A$. stammeri were present in a small proportion of boreholes and appear to be relatively uncommon in the Chalk. Although these species can be locally abundant in other geologies, they occur relatively rarely (Fig. 1a-c; see also Johns et al. 2015). Niphargus aquilex occurred in a small proportion of Chalk boreholes (Table 4), but there are many records from shallower sample sites (the hyporheic zone, springs and shallow wells; Fig. 1g), suggesting that presence may be lower in Chalk groundwater than in other habitats.

The English Chalk crops out over an area of more than $20,000 \mathrm{~km}^{2}$ and just the top 20 metres of the saturated zone contain 4,000 million $\mathrm{m}^{3}$ of water (British Geological Survey and UK Groundwater Forum, 2014). The aquifer and habitat are vertically much more extensive, and in areas where the Chalk has a thin cover, groundwater remains unconfined and well oxygenated, so it is likely that the habitat may also extend laterally into areas beyond the Chalk outcrop. This study found thousands of macro-invertebrates and thousands of Copepoda in only 198 boreholes. This represents a tiny fraction of the aquifer and therefore it is likely that there are millions to billions of macro-invertebrates and Copepoda present within the Chalk, which together with the microbial community, are likely to affect biogeochemical cycles in groundwater.

\section{Conclusions}

Investigating a single geological unit is useful to improve understanding of stygobitic invertebrates to guide their conservation and assess the services provided by subsurface ecosystems. Sampling boreholes in the same geological unit over a wide geographical area enabled patterns in species distributions to be more clearly understood than if multiple geologies or different environments had been sampled. This was the first extensive sampling of non-cavernous groundwater in northern England, and there were sufficient samples to establish that two stygobitic species present in southern England are very likely to be absent from northern England. However, the study also shows that three other species occur sufficiently rarely in southern England, that more sampling would be required to determine whether they are truly absent from northern England. The study includes some of the first records of $M$. leruthi, and revealed that this species is distributed throughout the Chalk of southern England.

Stygobitic invertebrates appear to be absent from the concealed Chalk where dissolved oxygen is low, but are remarkably common in boreholes in the unconcealed Chalk. They were common in boreholes with deep water tables, suggesting that the entire unconfined Chalk water supply aquifer contains an ecosystem comprising invertebrate communities that interact with microbial communities, and may influence biogeochemical cycles. The amphipod $N$. kochianus is very prevalent in southern England. Copepoda are also common, and occur in large numbers, but the controls on their distribution, and their role in ecosystem functioning remains unknown.

Overall, our study demonstrates that the English Chalk harbors an important ecosystem. The invertebrate species present are important to science because they are unusual organisms that are adapted to live in the subsurface environment where resources are sparse. Genetic studies (McInerney et al. 2014) show that the three Niphargus species found in the Chalk represent lineages that separated from their nearest relatives in continental Europe between 0.6 and 5.6 million years ago, and are therefore ancient species that have survived extreme climate and geological changes. As specialist organisms 
with their own habitat requirements they represent a unique component of biodiversity which offer opportunities for new scientific discoveries.

Acknowledgements We thank Adam Whalley, James Senior, Iain Murrell, Chris Di Marco, Simon Linford-Wood, Chris Hood and Pete Orton and other staff from the Environment Agency for enabling access to monitoring boreholes. Samples from Devon and Dorset were funded by the Esmee Fairbairn Foundation, grant number 08-101,7. We also thank Kat Manamsa and Barry Townsend for assistance with sampling, and Tim Guilford for commenting on the manuscript. This paper is published with the permission of the Director, British Geological Survey (NERC).

Open Access This article is distributed under the terms of the Creative Commons Attribution 4.0 International License (http:// creativecommons.org/licenses/by/4.0/), which permits unrestricted use, distribution, and reproduction in any medium, provided you give appropriate credit to the original author(s) and the source, provide a link to the Creative Commons license, and indicate if changes were made.

\section{References}

Allen DJ, Brewerton LJ, Coleby LM, Gibbs, BR, Lewis MA, MacDonald AM, Wagstaff SJ, Williams AT (1997) The physical properties of the major aquifers in England and Wales. BGS technical report WD/97/ 34, Environment Agency R\&D Publ. 8, Environment Agency, London, $312 \mathrm{pp}$

Allford AS, Cooper JB, Humphreys WF, Austin AD (2008) Diversity and distribution of groundwater fauna in a calcrete aquifer: does sampling method influence the story? Invertebr Syst 22(2):127-138

Ander EL, Shand, P, Griffiths KJ, Lawrence A, Hart, P, Pawley J (2004) Baseline Report Series: 13 The Great Ouse Chalk aquifer, East Anglia. British Geological Survey commissioned report CR/04/ 236N, BGS, Keyworth, UK, 75 pp

Ander EL, Shand P, Wood S (2006) Baseline Report Series: 21 The Chalk and Crag of north Norfolk and Waveney Catchment. British Geological Survey commissioned report CR/06/043, BGS, Keyworth, UK, $50 \mathrm{pp}$

Benjamini Y, Hochberg Y (1995) Controlling the false discovery rate: a practical and powerful approach to multiple testing. J R Stat Soc Ser B 57:289-300

Bloomfield JP (1996) Characterisation of hydrogeologically significant fracture distributions in the Chalk: an example from the Upper Chalk of southern England. J Hydrol 184(3-4):355-379

Bloomfield JP, Brewerton LJ, Allen DJ (1995) Regional trends in matrix porosity and dry density of the Chalk of England. Q J Eng Geol 28: S131-S142

Boulton AJ, Valett HM, Fisher SG (1992) Spatial distribution and taxonomic composition of the hyporheos of several Sonoran Desert streams. Arch Hydrobiol 125:37-61

Boulton AJ, Fenwick GD, Hancock PJ, Harvey MS (2008) Biodiversity, functional roles and ecosystem services of groundwater invertebrates. Invertebr Syst 22(2):103-116

British Geological Survey and UK Groundwater Forum (2014). Document on groundwater resources. http://www.groundwateruk. org/downloads/groundwater_resources.pdf. Accessed 1 Feb 2015

Culver DC, Christman MC, Elliott WR, Hobbs HH, Redell JR (2003) The North American obligate cave fauna: regional patterns. Biodiv Conserv 12(3):441-468

Danielopol DL (1989) Groundwater fauna associated with riverine aquifers. J N Am Benthol Soc 8:18-35
Deharveng L, Stoch F, Gibert J, Bedos A, Galassi D, Zagmajster M, Brancelj A, Camacho A, Fiers F, Martin P, Giani N, Magniez G, Marmonier P (2009) Groundwater biodiversity in Europe. Freshw Biol 54(4):709-726

Dobson AJ (2001) An introduction to generalized linear models, CRC, Boca Raton, FL

Dole-Olivier MJ, Malard F, Martin D, Lefebure T, Gibert J (2009) Relationships between environmental variables and groundwater biodiversity at the regional scale. Freshw Biol 54(4):797-813

Downing RA, Price M, Jones GP (2005) The hydrogeology of the Chalk of North-West Europe. Clarendon, Oxford, $308 \mathrm{pp}$

Eberhard SM, Halse SA, Williams MR, Scanlon MD, Cocking J, Barron HJ (2009) Exploring the relationship between sampling efficiency and short-range endemism for groundwater fauna in the Pilbara region, Western Australia. Freshw Biol 54(4):885-901

Edmunds WM, Doherty P, Griffiths KJ, Shand P (2002) Baseline Report Series: 4 The Chalk aquifer of Dorset. British Geological Survey commissioned report CR/02/268N, BGS, Keyworth, UK, 45 pp

Edmunds WM, Shand P, Hart P, Ward RS (2003) The natural (baseline) quality of groundwater: a UK pilot study. Sci Total Environ 310:2535

Galassi DMP, Stoch F, Fiasca B, Di Lorenzo T, Gattone E (2009) Groundwater biodiversity patterns in the Lessinian Massif of northern Italy. Freshw Biol 54(4):830-847

Gibert J, Culver DC (2009) Assessing and conserving groundwater biodiversity: an introduction. Freshw Biol 54(4):639-648

Gibson JR, Harden SJ, Fries JN (2008) Survey and distribution of invertebrates from selected springs of the Edwards Aquifer in Comal and Hays counties, Texas. Southwest Nat 53(1):74-84

Gledhill T, Sutcliffe DW, Williams WD (1993) British freshwater Crustacea Malacostraca: a key with ecological notes. Freshwater Biological Association, Ambleside, UK, 173 pp

Griebler C, Stein H, Kellermann C, Berkhoff S, Brielmann H, Schmidt S, Selesi D, Steube C, Fuchs A, Hahn HJ (2010) Ecological assessment of groundwater ecosystems: vision or illusion? Ecol Eng 36(9): $1174-1190$

Hahn HJ (2006) The GW-Fauna-Index: a first approach to a quantitative ecological assessment of groundwater habitats. Limnologica 36(2): 119-137

Hahn HJ, Fuchs A (2009) Distribution patterns of groundwater communities across aquifer types in south-western Germany. Freshw Biol 54(4):848-860

Hahn HJ, Matzke D (2005) A comparison of stygofauna communities inside and outside groundwater bores. Limnologica 35(1-2):31-44

Halse SA, Scanlon MD, Cocking JS (2002) Do springs provide a window to the groundwater fauna of the Australian arid zone? In: Yinfoo D (ed) Balancing the Groundwater Budget: Proceedings of an International Groundwater Conference, Darwin 2002. International Association of Hydrogeologists, Darwin, UK, pp 1-12

Hancock PJ, Boulton AJ (2008) Stygofauna biodiversity and endemism in four alluvial aquifers in Eastern Australia. Invertebr Syst 22(2): $117-126$

Hancock PJ, Boulton AJ (2009) Sampling groundwater fauna: efficiency of rapid assessment methods tested in bores in eastern Australia. Freshw Biol 54(4):902-917

Hancock PJ, Boulton AJ, Humphreys WF (2005) Aquifers and hyporheic zones: towards an ecological understanding of groundwater. Hydrogeol J 13(1):98-111

Hardman RFP (1982) Chalk reservoirs of the North Sea. Bull Geol Soc Den 30:119-137

Humphreys WF (2009) Hydrogeology and groundwater ecology: does each inform the other? Hydrogeol J 17(1):5-21

Johns T, Jones I, Knight L, Maurice L, Wood P, Robertson A (2015) Regional scale drivers of groundwater faunal distributions. Freshw Sci 34 (1):316-328. doi:10.1086/678460 
Jones HK, Morris BL, Cheney CS, Brewerton LJ, Merrin PD, Lewis MA, MacDonald AM, Coleby LM, Talbot J, McKenzie, AA, Bird MJ, Cunningham J, Robinson VK (2000) The physical properties of the minor aquifers of England and Wales. British Geological Survey technical report WD/00/4. Environment Agency R \& D publication 68, Environment Agency, London

Knight L (2011) The aquatic macro-invertebrate fauna of Swildon's Hole, Mendip Hills, Somerset, UK. Cave Karst Sci 38(2):81-92

Knight LRFD, Gledhill T (2010) The discovery of M. leruthi Schellenberg, 1934 (Crustacea: Amphipoda: Niphargidae) in Britain and its distribution in the British Isles. Zootaxa 2655:52-56

Korbel KL, Hose GC (2011) A tiered framework for assessing groundwater ecosystem health. Hydrobiologia 661(1):329-349

MacDonald AM, Allen DJ (2001) Aquifer properties of the Chalk of England. Q J Eng Geol 34:371-384

Macdonald AM, Brewerton L, Allen DJ (1998) Evidence for rapid groundwater flow and karst type behaviour in the Chalk of Southern England. In: Robins NS (ed) Groundwater pollution, aquifer recharge and vulnerability. Geol Soc London Spec Publ 130:95-106

Malard F, Hervant F (1999) Oxygen supply and the adaptations of animals in groundwater. Freshw Biol 41:1-30

Malard F, Mathieu J, Reybrobellet J, Lafont M (1996) Biomonitoring groundwater contamination: application to a karst area in southern France. Aquat Sci 58(2):158-187

Malard F, Boutin C, Camacho AI, Ferreira D, Michel G, Sket B, Stoch F (2009) Diversity patterns of stygobitic crustaceans across multiple spatial scales in Europe. Freshw Biol 54(4):756-776

Martin P, De Broyer C, Fiers F, Michel G, Sablon R, Wouters K (2009) Biodiversity of Belgian groundwater fauna in relation to environmental conditions. Freshw Biol 54(4):814-829

Maurice L, Bloomfield JP (2012) Stygobitic invertebrates in groundwater: a review of current knowledge from a hydrogeological perspective. Freshwater Rev 5(1):51-71

Maurice L, Atkinson TA, Barker JA, Bloomfield JP, Farrant AR, Williams AT (2006) Karstic behaviour of groundwater in the English Chalk. J Hydrol 330:53-62

Maurice LD, Atkinson TC, Barker JA, Williams AT, Gallagher A (2012) The nature and distribution of flowing features in a porous limestone aquifer with small-scale karstification. J Hydrol 438-439:3-15

McInerney CE, Maurice L, Robertson AL, Knight LRFD, Arnsheidt J, Venditti C, Dooley JSG, Mathers T, Matthijs S, Erikkson K, Proudlove G, Hanfling B (2014) The Ancient Britons: groundwater fauna survived extreme climate changes over tens of millions of years across NW Europe. Mol Ecol 23:1153-1166

Michel G, Malard F, Deharveng L, Di Lorenzo T, Sket B, De Broyer C (2009) Reserve selection for conserving biodiversity. Freshw Biol 54(4):861-876

Price M (1987) Fluid flow in the Chalk of England. Geochem Soc Spec Publ 34:141-156

Price M, Morris BL, Robertson AS (1982) A study of intergranular and fissure permeability in Chalk and Permian aquifers using double packer injection testing. J Hydrol 54:401-423
Price M, Downing RA, Edmonds WM (1993) The Chalk as an aquifer. In: Downing RA, Price M Jones GP (ed) The hydrogeology of the Chalk of North-West Europe. Oxford University Press, Oxford, UK, pp 35-59

Proudlove GS, Wood PJ, Harding PT, Horne DJ, Gledhill T, Knight LRFD (2003) A review of the status and distribution of the subterranean aquatic Crustacea of Britain and Ireland. Cave Karst Sci $30(2): 51-74$

Robertson AL, Wood PJ (2010) Ecology of the hyporheic zone: origins, current knowledge and future directions. Fundam Appl Limnol 176(4):279-289

Robertson AL, Smith JWN, Johns T, Proudlove GS (2009) The distribution and diversity of stygobites in Great Britain: an analysis to inform groundwater management. Q J Eng Geol Hydrogeol 42(3): 359-368

Schurch M, Buckely D (2002) Integrating geophysical and hydrochemical borehole log measurements to characterise the Chalk aquifer, Berkshire, United Kingdom. Hydrogeol J 10(6): 610-627

Shand P., Tyler-Whittle R, Besien T, Peach D, Lawrence AR, Lewis HO (2003) Baseline Report Series: 6 The Chalk aquifer of the Colne and Lee River catchments. British Geological Survey commissioned report CR/03/69N, BGS, Keyworth, UK, 55 pp

Sket B (1999) The nature of biodiversity in hypogean waters and how it is endangered. Biodivers Conserv 8:1319-1338

Smedley PL, Griffiths K, Tyler-Whittel R, Hargreaves R, Lawrence AR, Besien T (2003) Baseline Report Series: 5. The Chalk aquifer of Kent and East Surrey. British Geological Survey commissioned report CR/03/033N, BGS, Keyworth, UK, 57 pp

SmedleynPL, Neumann I, Farrell R (2004) Baseline Report Series: 10 The Chalk aquifer of Yorkshire and North Humberside. British Geological Survey commissioned report CR/04/128, BGS, Keyworth, UK, $50 \mathrm{pp}$

Smith DB, Downing RA, Monkhouse RA, Otlet RL, Pearson FJ (1976) The age of groundwater in the Chalk of the London Basin. Water Resour Res 12:392-404

Sorensen JPR, Maurice L, Edwards FK, Lapworth DJ, Read DS, Allen D, Butcher AS, Newbold LK, Townsend BR, Williams PJ (2013) Using boreholes as windows into groundwater ecosystems. Plos One 8(7):e70264

Stein H, Kellermann C, Schmidt SI, Brielmann H, Steube C, Berkhoff SE, Fuchs A, Hahn HJ, Thulin B, Griebler C (2010) The potential use of fauna and bacteria as ecological indicators for the assessment of groundwater quality. J Environ Monit 12:242-254

Ward JV, Palmer MA (1994) Distribution patterns of interstitial freshwater meiofauna over a range of spatial scales, with emphasis on alluvial river-aquifer systems. Hydrogbiologia 287: $147-156$

Whittaker RJ, Araújo MB, Jepson P, Ladle RJ, Watson JEM, Willis KJ (2005) Conservation biogeography: assessment and prospect. Diveris Distribut 11:3-23 